\title{
THE ENANTIOMERATION OF GINNING PERCENTAGE AT ADVANCED GENERATION OF COTTON HYBRIDS DEVELOPED BY METHODS OF ECOLOGIC- LONG GEOGRAPHICAL HYBRIDIZATION
}

\author{
Rano Abdurashidovna Yuldasheva \\ Candidate of Agricultural Sciences, Senior Researcher, Cotton Breeding, Seed Production and Cultivation \\ Agrotechnologies Research Institute, Tashkent, Uzbekistan
}

Shodmon Ergashevich Namazov

Doctor of Agricultural Sciences, Professor, Cotton Breeding, Seed Production and Cultivation Agrotechnologies Research Institute, Tashkent, Uzbekistan

\section{Guzal Ruzievna Kholmuradova}

Doctor of Agricultural Sciences, Professor of the Department of Genetics, Plant Breeding and Seed Production of Agricultural Crops, Tashkent State Agrarian University, University str., 3, Tashkent-100140, Uzbekistan.

\section{Khusniddin Kholbozorovich Mardanov}

Independent Researcher, Associate Professor of the Department of Genetics, Plant Breeding and Seed Production of Agricultural Crops, Tashkent State Agrarian University, University str., 3, Tashkent-100140, Uzbekistan.

DOI: https://doi.org/10.36713/epra3823

\begin{abstract}
Despite the greater achievements in the cotton breeding, in this article the issue of developing of initial materials was presented which hasn't been almost studied yet for the breeding of the varieties with high (+)-gossypol traits through some breeding aspects including determination of the accessions with low total gossypol or nontoxic (+)-gossypol enantiomer among the world cotton germpool accessions, and involving them to breeding process. It has been emphasized that the researches on this concern are the prior tasks corresponding to the requirements of today and the future also the efficiency of of these varieties with positive traits in national economy, livestock husbandry and food industry. As research results it was noted that, there was possibility to select sustainable cotton progenies with high complex of agronomic valuable traits and high lint percentage among the $F_{8}-F_{9}$ developed by the method of ecologico- geographical long hybridization. Furthermore, it was concluded that the results of hybridization of the USA accessions with a high level of (+)-gossypol in seeds and local varieties were successful for both as developing of breeding material with high level of nontoxic (+)gossypol in seeds and high lint percentage.
\end{abstract}

KEYWORDS: cotton progenies, ecologico-geographical long hybridization, gossypol enantiomers, lint percentage. 


\section{INTRODUCTION}

It is known, that cotton varieties have great trait finance not only for its fiber, but also for the seed products in national economy. Because, the cotton seed is an essential source of oil and high protein feed concentration.

The USDA National Agricultural Statistics Service estimated that the world production of cottonseed in 1999-2000 was over 33.3 million metric tons. Cottonseed is composed of $\sim 22.5 \%$ protein. If $5 \%$ of world cottonseed production is retained for replanting, the remaining 7.12 million metric tons of protein could be available for human consumption, if the cottonseed was free of toxic (-)-gossypol. This is sufficient protein to provide for the needs for $345 \mathrm{M}$ people $(>5 \%$ of the world's population) for one year if the USDA recommendation of $56.5 \mathrm{~g}$ of protein per day per person was followed.

In accordance wit US external agricultural service, in 2009 about 2.250.000 tons of cotton seed were produced in our country [13]. However, due to toxity of gossypol in the seed, protein and oil taken from this seed cannot be used directly. Usually seeds are physically processed or can be cleaned from gossypol by chemical methods. This method requires much time and money. Cotton cake also can't be used in much amount for animals feed.

Despite the greater achievements in the cotton breeding, in this article the issue of developing of initial materials was presented which hasn't been almost studied yet for the breeding of the varieties with gossypol traits through some breeding aspects including determination of the variety accessions with seeds of less amount of gossypol or of low toxic (+)- gossypol enantiomer among the world cotton germpool accessions, and introducing them to breeding processes. Therefore, the efficiency of positive traits of these varieties is higher in national economy, livestock husbandry and food industry, moreover, it has been emphasized that the researches on this concern are the prior tasks corresponding to the requirements of today and the future.

In Uzbekistan several researches were carried toward the study of cotton plant without gossypol and developing of cotton varieties without gossypol $[8,10$, 11]. They were mostly intended to study genetic material and to determining of the initial materials for breeding on the base of foreign varieties. As result of conducted investigations there developed some breeding accessions and the variety Bukhara-9 [1]. It was noted that cotton plant varieties with low toxic gossypol were not implemented in production in the Republic.

US scientists determined two active optical enantiomers of gossypol, that is, (+)- and (-) -gossypol $[3,7,12]$. In cotton (Gossypium) the ratio of $(+)-$ to (-)-gossypol can vary from 98:2 to $31: 69$ in seed $[4,9]$. Within the genus Gossypium, it was found accessions from several species that have $>92 \%(+)$-gossypol in the seed.

As well as, among accessions the ratio between (+)-gossypol and (-) gossypol was 3:2. These enantiomers of gossypol were found to be harmful and cause different poisoning to non-ruminants and (-)gossypol is harmful for hot-blooded animals. According to scientists, the transference of $(+)$-gossypol trait into cultivated varieties allow to produce valuable feed for non-ruminants, while transference of (-)- gossypol can be useful in medicine. That's why, in the literatures published in recent years, there is an information about the new trend, that is, the breeding of cotton plants with high (+)- gossypol. As they stated, it is one of vital issue to develop the varieties with the less gossypol or low toxic (+)- gossypol in the seeds for the feeding livestock and solution of the problem of food nowadays.

The investigations are being conducted by US scientists on transference of $(+)$ - gossypol trait from Gossypium ssp. marie galante cotton plant to cultural varieties [2]. But, the investigations toward developing of initial material hasn't been carried out yet in Uzbekistan for the breeding of the varieties with $(+)$ gossypol. If we consider the developing of cotton plant varieties that are low toxic or with high (+)- gossypol level in seeds for man and animals, that their introduction into practice, are of great economical importance. Thus the researches on this aspect are undoubtedly, important theoretically and practically.

The aim of the research is to develop cotton varieties with high level of (+)-gossypol in seeds and such agronomic valuable traits as lint percentage on the base of analysis of sustainability of trait among the progenies.

\section{MATERIALS AND METHODS}

There are used common adopted methods of phenological observations and laboratory analyses were conducted during the dissertation researches. The analyses of the total and (+)-gossypol level of the seeds of the studied varieties, and accessions and hybrids were carried out in the Institute of Bioorganic Chemistry of Academy Science of Republic of Uzbekistan. All statistical analyses were conducted by the methods of B.A. Dospekhov [5].

\section{RESULTS AND DISCUSSION}

It is known that the lint percentage is of important agronomic valuable traits. Therefore, we have investigated formation and stability of this trait at ecologic-geographical and genetic long hybrids in our researches.

As we know, any cotton plant vareity is evaluated firstly for its yield amount and quality. That's why, we have also studied the process of formation of lint percentage of $\mathrm{F}_{8}$ progenies (Table 1).

It was observed that in $\mathrm{F}_{8}$ progenies the lint percentage was higher than in standard variety S-6524 in some cases. Among them only 2 hybrid combinations $\mathrm{F}_{8} \mathrm{~S}-6524 \times \mathrm{BC}_{3} \mathrm{~S}_{1}-47-8-1-17$ and $\mathrm{F}_{8} \mathrm{~S}-6532 \times \mathrm{BC}_{3} \mathrm{~S}_{1}-1-6-$ $3-15$ presented a bit higher lint percentage (accordingly, $37.8 \%$ and $37.6 \%$ ). The rest of progenies were on the same level of standard variety or privilege over it. Particularly, the lint percentage of $\mathrm{F}_{8} \mathrm{BC}_{3} \mathrm{~S}_{1}-1-6-3-15 \times$ $\mathrm{S}-6532, \mathrm{~F}_{8} \mathrm{~S}-6530 \times \mathrm{BC}_{3} \mathrm{~S}_{1}-1-6-3-15$ and $\mathrm{F}_{8} \mathrm{~L}-16 / 04 \times$ $\mathrm{BC}_{3} \mathrm{~S}_{1}$-1-6-3-15 progenies were found out to be more than $36,0 \%$. 
Table 1

The formation of lint percentage trait of among the $F_{8}$ progenies developed by the method of long ecologic-geographical hybridization (\%), 2015.

\begin{tabular}{|c|c|c|c|c|}
\hline \multirow{2}{*}{ № } & \multirow{2}{*}{ Progenies } & \multicolumn{3}{|c|}{ Lint percentage, $\%$} \\
\hline & & $\mathbf{M} \pm \mathbf{m}$ & $\sigma$ & $\mathrm{V}, \%$ \\
\hline 1 & $\mathrm{BC}_{3} \mathrm{~S}_{1}-1-6-3-4-15$ & $36,8 \pm 2,34$ & 2,68 & 12,71 \\
\hline 2 & $\mathrm{~F}_{8} \mathrm{BC}_{3} \mathrm{~S}_{1}-47-8-1-17 \times \mathrm{S}-6524$ & $34,4 \pm 0,68$ & 2,05 & 5,97 \\
\hline 3 & $\mathrm{~F}_{8} \mathrm{BC}_{3} \mathrm{~S}_{1}-47-8-1-17 \times \mathrm{S}-6530$ & $34,6 \pm 0,60$ & 1,80 & 5,21 \\
\hline 4 & $\mathrm{~F}_{8} \mathrm{BC}_{3} \mathrm{~S}_{1}-47-8-1-17 \times \mathrm{S}-6532$ & $34,7 \pm 0,72$ & 1,90 & 5,65 \\
\hline 5 & $\mathrm{~F}_{8} \mathrm{BC}_{3} \mathrm{~S}_{1}-1-6-3-15 \times \mathrm{S}-6524$ & $34,6 \pm 0,40$ & 1,15 & 3,37 \\
\hline 6 & $\mathrm{~F}_{8} \mathrm{BC}_{3} \mathrm{~S}_{1}-1-6-3-15 \times \mathrm{S}-6530$ & $35,9 \pm 1,56$ & 3,13 & 8,72 \\
\hline 7 & $\mathrm{~F}_{8} \mathrm{BC}_{3} \mathrm{~S}_{1}-1-6-3-15 \times \mathrm{S}-6532$ & $36,7 \pm 0,90$ & 2,38 & 6,53 \\
\hline 8 & $\mathrm{~F}_{8} \mathrm{~S}-6524 \times \mathrm{BC}_{3} \mathrm{~S}_{1}-47-8-1-17$ & $37,8 \pm 1,53$ & 2,66 & 7,13 \\
\hline 9 & $\mathrm{~F}_{8} \mathrm{~S}-6530 \times \mathrm{BC}_{3} \mathrm{~S}_{1}-47-8-1-17$ & $36,2 \pm 0,84$ & 2,91 & 8,03 \\
\hline 10 & $\mathrm{~F}_{8} \mathrm{~S}-6524 \times \mathrm{BC}_{3} \mathrm{~S}_{1}-1-6-3-15$ & $36,4 \pm 0,45$ & 0,78 & 2,14 \\
\hline 11 & $\mathrm{~F}_{8} \mathrm{~S}-6530 \times \mathrm{BC}_{3} \mathrm{~S}_{1}-1-6-3-15$ & $36,8 \pm 0,64$ & 1,70 & 4,64 \\
\hline 12 & $\mathrm{~F}_{8} \mathrm{~S}-6532 \times \mathrm{BC}_{3} \mathrm{~S}_{1}-1-6-3-15$ & $37,6 \pm 0,92$ & 1,45 & 3,36 \\
\hline 13 & $\mathrm{~F}_{8} \mathrm{~L}-10 / 04 \times \mathrm{BC}_{3} \mathrm{~S}_{1}-47-8-1-17$ & $34,9 \pm 0,73$ & 1,67 & 3,89 \\
\hline 14 & $\mathrm{~F}_{8} \mathrm{~L}-16 / 04 \times \mathrm{BC}_{3} \mathrm{~S}_{1}-47-8-1-17$ & $35,02 \pm 0,74$ & 2,10 & 6,00 \\
\hline 15 & $\mathrm{~F}_{8} \mathrm{~L}-16 / 04 \times \mathrm{BC}_{3} \mathrm{~S}_{1}-1-6-3-15$ & $36,8 \pm 0,98$ & 2,96 & 8,09 \\
\hline 16 & S-6524 (standard) & $36,6 \pm 0,88$ & 2,33 & 3,13 \\
\hline
\end{tabular}

By the lint percentage, all studied progenies have showed lower dates according to dispersion indications, that is, presented the smoothness by the traits.

It was also determined that dispersion of hybrids were from $0,78 \%\left(\mathrm{~F}_{8} \mathrm{~S}-6524 \times \mathrm{BC}_{3} \mathrm{~S}_{1}-1-6-3-15\right.$ up to $3,13 \%\left(\mathrm{~F}_{8} \mathrm{BC}_{3} \mathrm{~S}_{1}-1-6-3-15 \times \mathrm{S}-6530\right)$, while the standard variety dispersion was $2,33 \%$. Variation of the lint percentage of almost all progenies (except $\mathrm{F}_{8} \mathrm{~S}-6524 \times$ $\left.\mathrm{BC}_{3} \mathrm{~S}_{1}-47-8-1-17\right)$ was higher than standard variety and ranged between $3,36 \%\left(\mathrm{~F}_{8} \mathrm{~S}-6532 \times \mathrm{BC}_{3} \mathrm{~S}_{1}-1-6-3-15\right)$ and $8.7 \%\left(\mathrm{~F}_{9} \mathrm{BC}_{3} \mathrm{~S}_{1}-1-6-3-15 \times \mathrm{S}-6530\right)$.

According to the dates, obtained in 2016, the lint percentage of $\mathrm{F}_{9}$ progenies were more positive

compared to other agronomic valuable traits (Table 2). It was noted that the lint percentage of US accession was higher $(38,9 \%)$. And most of progenies developed by participation of this accession showed comparatively higher lint percentage. For an example, we can take $\mathrm{F}_{9} \mathrm{~S}$ $6530 \times \mathrm{BC}_{3} \mathrm{~S}_{1}-47-8-1-17, \mathrm{~F}_{9} \mathrm{~S}-6532 \times \mathrm{BC}_{3} \mathrm{~S}_{1}-47-8-1-17$, and $\mathrm{F}_{9} \mathrm{~S}-6530 \times \mathrm{BC}_{3} \mathrm{~S}_{1}-1-6-3-15, \mathrm{~F}_{9} \mathrm{~S}-6532 \times \mathrm{BC}_{3} \mathrm{~S}_{1}-1-$ 6-3-15 progenies. Lint percentage of these progenies ranged between 39,4-40\% and more. The results of these progenies were higher on $3 \%$ than standard variety, while the indications of $\mathrm{F}_{9} \mathrm{~L}-10 / 04 \times \mathrm{BC}_{3} \mathrm{~S}_{1}-47$ 8-1-17 and $\mathrm{F}_{9} \mathrm{~L}-16 / 04 \times \mathrm{BC}_{3} \mathrm{~S}_{1}-47-8-1-17$ hybrids were found to be considerably higher than in standard variety.

Table 2

g the $F_{9}$ progenies developed by the method of long ecologic-geographical hybridization (\%), 2016.

\begin{tabular}{|l|l|c|c|c|}
\hline \multicolumn{1}{|c|}{ № } & \multicolumn{1}{|c|}{ Progenies } & $\mathbf{M} \pm \mathbf{m}$ & $\boldsymbol{\sigma}$ & $\mathbf{V}, \mathbf{\%}$ \\
\hline 1 & $\mathrm{BC}_{3} \mathrm{~S}_{1}-1-6-3-4-15$ & $38,9 \pm 0,83$ & 1,86 & 4,79 \\
\hline 2 & $\mathrm{~F}_{9} \mathrm{BC}_{3} \mathrm{~S}_{1}-47-8-1-17 \times \mathrm{S}-6524$ & $38,2 \pm 0,53$ & 2,40 & 6,28 \\
\hline 3 & $\mathrm{~F}_{9} \mathrm{BC}_{3} \mathrm{~S}_{1}-47-8-1-17 \times \mathrm{S}-6530$ & $38,2 \pm 0,50$ & 1,69 & 4,43 \\
\hline 4 & $\mathrm{~F}_{9} \mathrm{BC}_{3} \mathrm{~S}_{1}-47-8-1-17 \times \mathrm{S}-6532$ & $37,6 \pm 0,75$ & 2,49 & 6,63 \\
\hline 5 & $\mathrm{~F}_{9} \mathrm{BC}_{3} \mathrm{~S}_{1}-1-6-3-15 \times \mathrm{S}-6524$ & $37,1 \pm 0,42$ & 1,54 & 4,14 \\
\hline 6 & $\mathrm{~F}_{9} \mathrm{BC}_{3} \mathrm{~S}_{1}-1-6-3-15 \times \mathrm{S}-6530$ & $39,2 \pm 0,40$ & 1,68 & 4,30 \\
\hline 7 & $\mathrm{~F}_{9} \mathrm{BC}_{3} \mathrm{~S}_{1}-1-6-3-15 \times \mathrm{S}-6532$ & $37,9 \pm 1,13$ & 2,77 & 7,31 \\
\hline 8 & $\mathrm{~F}_{9} \mathrm{~S}-6524 \times \mathrm{BC}_{3} \mathrm{~S}_{1}-47-8-1-17$ & $38.0 \pm 1,23$ & 2,52 & 5,23 \\
\hline 9 & $\mathrm{~F}_{9} \mathrm{~S}-6530 \times \mathrm{BC}_{3} \mathrm{~S}_{1}-47-8-1-17$ & $39,5 \pm 0,62$ & 1,77 & 4,47 \\
\hline 10 & $\mathrm{~F}_{9} \mathrm{~S}-6532 \times \mathrm{BC}_{3} \mathrm{~S}_{1}-47-8-1-17$ & $40,1 \pm 1,06$ & 2,13 & 5,31 \\
\hline 11 & $\mathrm{~F}_{9} \mathrm{~S}-6524 \times \mathrm{BC}_{3} \mathrm{~S}_{1}-1-6-3-15$ & $37,5 \pm 0,74$ & 1,83 & 4,89 \\
\hline 12 & $\mathrm{~F}_{9} \mathrm{~S}-6530 \times \mathrm{BC}_{3} \mathrm{~S}_{1}-1-6-3-15$ & $39,2 \pm 0,58$ & 1,55 & 3,96 \\
\hline 13 & $\mathrm{~F}_{9} \mathrm{~S}-6532 \times \mathrm{BC}_{3} \mathrm{~S}_{1}-1-6-3-15$ & $40,9 \pm 0,37$ & 1,05 & 2,50 \\
\hline 14 & $\mathrm{~F}_{9} \mathrm{~L}-10 / 04 \times \mathrm{BC}_{3} \mathrm{~S}_{1}-47-8-1-17$ & $39,4 \pm 0,87$ & 1,94 & 4,93 \\
\hline 15 & $\mathrm{~F}_{9} \mathrm{~L}-16 / 04 \times \mathrm{BC}_{3} \mathrm{~S}_{1}-47-8-1-17$ & $37,1 \pm 0,54$ & 2,10 & 5,65 \\
\hline 16 & $\mathrm{~F}_{9} \mathrm{~L}-16 / 04 \times \mathrm{BC}_{3} \mathrm{~S}_{1}-1-6-3-15(\mathrm{~N}-4)$ & $39,2 \pm 0,74$ & 2,56 & 6,54 \\
\hline 17 & $\mathrm{~S}_{-6524}(\mathrm{standard})$ & $38,5 \pm 0,87$ & 2,31 & 5,99 \\
\hline
\end{tabular}


A bit lower results were obtained in $\mathrm{F}_{9} \mathrm{BC}_{3} \mathrm{~S}_{1}-1-6$ $3-15 \times \mathrm{S}-6524 \quad 37,1 \%$ and $\mathrm{F}_{9} \mathrm{~S}-6524 \times \mathrm{BC}_{3} \mathrm{~S}_{1}-1-6-3-$ 15 progenies $(35,7 \%)$. Thus, research results of formation and stability processes among the progenies developed between the USA cotton accessions and local varieties showed, the influence of USA ones with high lint percentage were positive for creating of breeding material combining high level of (+)-gossypol in seeds and high lint yield.

\section{CONCLUSION}

Research results of advanced generations developed by the method of ecologic-geographical long hybridization showed possibility of selecting sustainable cotton plant progenies among the $\mathrm{F}_{8}-\mathrm{F}_{9}$ hybrids with high complex of agronomic valuable traits and breeding of toward improving of this trait more effective, if in the hybridization will be used as male parental form USA accessions with high lint percentage.

\section{REFERENCES}

1. Batalov A.M., Nematov Kh.Sh., Rakhmatov B. (2014). "Bukhara-9" variety with zero harmful gossypol in the content of seeds developed in Bukhara region. //The collection of materials from the Republican scientificpractical conference named "Perspectives of developing cotton growing in Uzbekistan" ( I-part).-Tashkent, 2014. 147-152.

2. Beil G.M., Atkins R.E. (1965). Intermittent in quantitative characters in grain sorghum. Iowa state journal of science. 39 (3): 35-37.

3. Blackstaffe L., Shelley M. D., Fish R. G. (1997). Cytotoxicity of gossypol enantiomers and its quinone metabolite gossypolone in melanoma cell lines. Melanoma Res. 7:364-372.

4. Cass, Q. B., Tiritan, E., Matlin, S. A., Freire, E. C. (1991). Gossypol enantiomer ratios in cotton seeds. Phytochemistry 30:2655-2657.

5. Dospekhov B.A. (1985). Methods of field experiments.Moscow: Agropromizdat, $351 \mathrm{p}$.

6. Frampton V.L., Edwards J.D. (1948). Determination of (+)-gossypol amount.

7. Joseph A.E., Martin S.A., Knox P. (1986). Cytotoxicity of enantiomers of gossypol. Br. J. Cancer 54: 511-513.

8. Nurimov G.N. (1972). Study of collections with gossypol content // Collection of works on genetics, breeding and seed-breeding of cotton plant. Tashkent, pp. 208-214.

9. Percy, R. G., Calhoun, M. C., Kim, H. L. (1996). Seed gossypol variation within Gossypium barbadense L. cotton. Crop Sci. 36:193-197.

10. Rjekhin V.P. (1955). Gossypol and its derivatives // Journal of practical chemistry. 2:44-46.

11. Sadikov A.S. (1958). New method of determining gossypol in different vegetative bodies of cotton plant. Journal of SA of UzR. Chem.chapter. Nauk. 4: 14-18.

12. Wang N.G., Zhou L.F., Guan M.Z., Lei H.P. 1987. Effects of (-)- and (+)-gossypol on fertility in male rats. J. Ethnopharmacol. 20:21-24.

13. http://www.fas.usda.gov/psdonline 